\title{
Hubungan Konsumsi Antioksidan dari Makanan dengan Beta- Amyloid Plasma sebagai Penanda Gangguan Fungsi Kognitif pada Lanjut Usia
}

\author{
Ratna D Siregar ${ }^{1}$, Nur Indrawati Lipoeto ${ }^{2}$, Yuliarni Syafrita ${ }^{3}$
}

\begin{abstract}
Abstrak
Penelitian ini bertujuan untuk mengetahui hubungan antara konsumsi vitamin $\mathrm{A}$, vitamin $\mathrm{C}$, vitamin $\mathrm{E}$, zink dan selenium dari makanan dengan fungsi kognitif pada lanjut usia. Metoda penelitian adalah cross sectional study terhadap 145 lansia umur $\geq 60$ tahun, pada dua kecamatan di Kabupaten Lima Puluh Kota Sumatra Barat. Wawancara konsumsi antioksidan menggunakan Food Frequency Questionnaires (FFQ), fungsi kognitif diperiksa dengan Montreal Cognitive Assesment versi Indonesia (MoCA-Ina), A 340 dan A $\beta 42$ plasma diperiksa dengan metode ELISA. Data dianalisis menggunakan uji Mann-Whitney dan Chi-square. Pada hasil penelitian ditemukan 83 orang $(57,2 \%)$ lansia yang mengalami gangguan fungsi kognitif. Terdapat hubungan yang signifikan antara konsumsi vitamin $C(p<0,049)$ dan vitamin $E(p<0,037)$ tetapi tidak terdapat hubungan signifikan antara vitamin $A$, zink dan selenium dengan fungsi kognitif. Tidak terdapat hubungan yang signifikan antara konsumsi antioksidan dengan tingkat $A \beta 40$ dan $A \beta 42$ serta antara tingkat $A \beta 40$ dan $A \beta 42$ dengan fungsi kognitif masing-masing ( $p<0,058$ dan $p<0,350$ ). Kesimpulan hasil penelitian ini didapatkan hubungan antara konsumsi vitamin $C$ dan vitamin $E$ dari makanan dengan fungsi kognitif. Tetapi tidak terdapat hubungan antara konsumsi antioksidan dengan $A \beta 40$ dan $A \beta 42$ plasma dan $A \beta 40$ dan $A \beta 42$ dengan fungsi kognitif.
\end{abstract}

Kata kunci: antioksidan, beta-amyloid, fungsi kognitif, lanjut usia

\section{Abstract}

The objective of this study was to determine the relationship between consumption of vitamin $A$, vitamin $C$, vitamin $E$, zinc and selenium from foods with cognitive function in elderly. This was a cross-sectional study that was conducted to 145 elderly with age $\geq 60$ years, in two districts in West Sumatra, in Lima Puluh Kota city. Interview antioxidant intake using a Food Frequency Questionnaires (FFQ), cognitive function was checked by Montreal Cognitive Assessment Indonesian version (MoCA-Ina), plasma A 40 dan A 42 were examined by ELISA while the data were analyzed by using the Mann-Whitney and Chi-square test. Results : Eighty three elderly people (57.2\%) were found with impaired cognitive function. There was a significant association between the consumption of vitamin $C$ $(p<0.049)$ and vitamin $E(p<0.037)$ but there was no signifikan association between vitamin $A$, zinc and selenium with cognitive function. There was no significant association between consumption of the antioxidant and both plasma $A \beta 40$ and $A \beta 42$ levels. There was no significant between levels of $A \beta 40$ and $A \beta 42$ and cognitive function $(p<0.058$ and $p<0.350$, respectively).Conclusion : There is a association between the consumption of vitamin $C$ and vitamin $E$ from food and cognitive function, but there is no association between the consumption of the antioxidant and levels of plasma $A \beta 40$ and $A \beta 42$ and between levels of plasma $A \beta 40$ and $A \beta 42$ and cognitive function.

Keywords: antioxidants, amyloid-beta, cognitive function, elderly

Affiliasi penulis : : 1. Program Studi Magister Biomedik FK UNAND (Fakultas Kedokteran Universitas Andalas Padang, 2. Bagian IImu Gizi FK UNAND, 3. Bagian Neurologi FK UNAND
Korespondensi :Ratna D Siregar, Email: ratnadelia_siregar@yahoo.com, Telp: :081366498172 


\section{PENDAHULUAN}

Peningkatan jumlah lansia (lanjut usia) dan umur harapan hidupnya menyebabkan meningkat pula penyakit yang timbul akibat proses penuaan. Otak merupakan salah satu organ yang rentan terhadap proses penuaan atau degeneratif. Berbagai penyakit degeneratif otak seperti demensia alzheimer, demensia vaskuler dan Parkinson sampai saat ini pengobatannya belum memberikan hasil yang diharapkan. ${ }^{1}$ Teori stres oksidatif merupakan teori yang paling baik menjelaskan mekanisme penuaan. Meningkatnya stress oksidatif pada usia lanjut menyebabkan penumpukan produk oksidasi lipid, asam nukleat dan protein yang akhirnya menyebabkan disfungsi sel dan menurunkan daya tahan tubuh terhadap agen perusak dari luar. ${ }^{2}$

Teori kaskade amyloid merupakan teori yang banyak diyakini para ahli sebagai penanda pada demensia. Penelitian pada hewan dan manusia menunjukkan adanya penumpukan beta-amyloid $(A B)$ yang merupakan komponen utama plak senilis pada otak penderita demensia alzheimer. Bentuk oligomer $A \beta$ secara langsung menghasilkan $\mathrm{H}_{2} \mathrm{O}_{2}$ dan meningkatkan produksi ROS (Reactive Oxygen Species) di mitokondria. ${ }^{3}$ A $\beta 40$ dan $A \beta 42$ merupakan penanda yang paling signifikan menunjukkan adanya gangguan fungsi kognitif terutama pada demensia. ${ }^{4}$ Strategi pencegahan primer penyakit neurodegeneratif tersebut adalah dengan mengendalikan faktor resikonya seperti penyakit hipertensi, diabetes melitus, hiperkholesterolemia, rokok dan gizi ${ }^{5}$ Salah satu caranya adalah dengan meningkatkan konsumsi makanan yang mengandung antioksidan diantaranya vitamin $A$, vitamin $E$, vitamin $C$, zink dan selenium. ${ }^{6}$ Vitamin $C$ terbukti dapat mengurangi oligomer $A \beta$ dan stres oksidatif secara in vitro dan in vivo, sedangkan vitamin $\mathrm{E}$ merupakan antioksidan yang melindungi sel saraf dengan menghambat stres oksidatif dan scavenger radikal bebas yang dihubungkan dengan $A \beta{ }^{7}$

Daerah Lima Puluh Kota di kenal memiliki perkebunan gambir, sayur dan buah yang lebih banyak dari kabupaten lain di Sumatera Barat sehingga masyarakat di sana tidak mengalami kesulitan dalam memperoleh sumber antioksidan dari sayur dan buah.
Berdasarkan data tersebut, penelitian ini dilakukan untuk mengetahui lebih jauh hubungan konsumsi antioksidan yang diperoleh dari makanan seperti vitamin $A$, vitamin $C$, vitamin $E$, zink dan selenium dengan fungsi kognitif dan hubungannya dengan beta-amyloid plasma, sehingga dapat membantu memperlambat atau mencegah penurunan fungsi kognitif pada lansia.

\section{METODE}

Desain penelitian ini adalah cross sectional study pada lansia berumur $\geq 60$ tahun yang sesuai dengan kriteria inklusi dan eksklusi pada dua kecamatan di Kabupaten Lima Puluh Kota Sumatra barat dari April sampai Agustus 2014. Sebanyak 150 orang diperoleh dengan rumus deskriptif kategorik, ${ }^{8}$ kemudian dipilih berdasarkan multistage random sampling dan systematic random sampling.

Data konsumsi makanan antioksidan dari makanan diperoleh menggunakan Food Frequency Questionneires (FFQ), fungsi kognitif diperoleh dengan pemeriksaan Montreal Cognitive assesment versi Indonesia (MoCA-Ina) dan pemeriksaan Aß40 dan A 42 dilakukan dengan metode ELISA di laboratorium Biomedik Fakultas Kedokteran Unand Padang.

Gambaran karakteristik responden seperti jenis kelamin, pendidikan, pekerjaan, merokok, tekanan darah, kadar glukosa darah dan status gizi ditampilkan dalam bentuk tabel proporsi atau persentase (univariat). Kadar $A \beta 40$ dan $A \beta 42$ pada penelitian ini belum memiliki nilai normal pada populasi oleh sebab itu ditentukan titik potong (cut-off point) optimal terhadap nilai MoCA-Ina pada nilai 26 (kognitif baik) dengan prosedur Receiver Operating Characteristic (ROC). Pengolahan data untuk mengetahui hubungan antara konsumsi antioksidan vitamin $\mathrm{A}, \mathrm{C}, \mathrm{E}$, zink dan selenium dengan gangguan fungsi kognitif dan beta-amyloid menggunakan uji komparatif Mann-Whitney karena distribusi data tidak normal. Hubungan kategori beta-amyloid dengan fungsi kognitif diperiksa dengan Chi-Square test. Data dianalisis secara komputerisasi. Signifikan ditentukan dengan nilai $p<0,05$.

\section{HASIL}

Jumlah subjek adalah 150 orang lansia, namun setelah dilakukan cleaning data terdapat 2 
orang lansia dikeluarkan dari penelitian karena memiliki konsumsi kalori kurang dari 500 kkal/hari dan 3 orang memiliki konsumsi kalori lebih dari 4000 $\mathrm{kkal} /$ hari, Hal ini dikhawatirkan akan mengakibatkan underestimate atau overestimate, ${ }^{8}$ sehingga besar sampel yang diperiksa berjumlah 145 orang. Karakteristik responden secara umum dapat dilihat pada tabel 1 dibawah ini.

Tabel 1. Karakteristik Responden

\begin{tabular}{|c|c|c|c|}
\hline Variab & & $\mathrm{n}$ & $\%$ \\
\hline Umur & רun) & & \\
\hline$-60-64$ & & 72 & 49,7 \\
\hline$-65-69$ & & 29 & 20 \\
\hline$-70-74$ & & 28 & 19,3 \\
\hline$-\geq 75$ & & 16 & 11 \\
\hline Jenis $\mathrm{k}$ & $\operatorname{amin}$ & & \\
\hline- & Laki-laki & 30 & 20,7 \\
\hline - & Perempuan & 115 & 79,3 \\
\hline Pendid & & & \\
\hline- & SD & 107 & 73,8 \\
\hline - & SMP & 26 & 17,9 \\
\hline - & SMA & 5 & 3,4 \\
\hline- & PT & 7 & 4,8 \\
\hline Pekerj & & & \\
\hline- & $\mathrm{PNS} / \mathrm{TNI}$ & 55 & 37,9 \\
\hline - & Wiraswasta & 1 & 0,7 \\
\hline - & Pedagang & 5 & 3,4 \\
\hline - & Buruh/tani & 84 & 57,9 \\
\hline Indeks & kok & & \\
\hline- & Tidak merokok & 116 & 80 \\
\hline - & Ringan & 14 & 9,7 \\
\hline - & Sedang & 7 & 4,8 \\
\hline - & Berat & 8 & 5,5 \\
\hline BMI & & & \\
\hline- & $<18,5$ & 21 & 14,5 \\
\hline - & $18,5-23$ & 76 & 52,4 \\
\hline - & $>23$ & 48 & 33,1 \\
\hline DM & & & \\
\hline - & Tidak DM & 134 & 92,4 \\
\hline - & DM & 11 & 7,6 \\
\hline Hiperte & & 86 & 59,3 \\
\hline- & Tidak hipertensi & 59 & 40,7 \\
\hline Total & Hipertensi & 145 & 100 \\
\hline
\end{tabular}

Tabel 1 menunjukkan bahwa sebagian besar responden berumur antara 60 sampai 64 tahun $(49,7 \%)$, jenis kelamin perempuan $(79,3 \%)$ dan lebih dari separuh berpendidikan SD (73,8\%). Buruh atau tani merupakan pekerjaan sebagian besar responden $(57,9 \%)$. Sebanyak $80 \%$ responden tidak merokok dan $5,5 \%$ memiliki indeks rokok berat. Lebih dari separuh responden memiliki BMI normal $(52,4 \%)$ dan sebagian besar responden tidak memiliki penyakit diabetes melitus (92,4\%) dan hipertensi (59,3\%).
Tabel 2. Distribusi Konsumsi Antioksidan Vitamin A, Vitamin C, Vitamin E, Zink dan Selenium perhari.

\begin{tabular}{|c|c|c|c|c|c|}
\hline $\begin{array}{l}\text { Konsumsi } \\
\text { antioksidan }\end{array}$ & $\begin{array}{c}\text { Rerata } \pm \\
\text { SD }\end{array}$ & Median & Min & Maks & $\mathrm{AKG}^{\star}$ \\
\hline $\begin{array}{l}\text { Vitamin A } \\
(\mu g \mathrm{RE} / \mathrm{hr})\end{array}$ & $784 \pm 249$ & 822 & 206 & 1142 & 600 \\
\hline $\begin{array}{l}\text { Vitamin C } \\
(\mathrm{mg} / \mathrm{hr})\end{array}$ & $92 \pm 42$ & 88 & 20 & 194 & 75 \\
\hline $\begin{array}{l}\text { Vitamin E } \\
(\mathrm{mg} / \mathrm{hr})\end{array}$ & $19 \pm 9$ & 17 & 5 & 40 & 15 \\
\hline $\begin{array}{l}\text { Zink } \\
\text { (mg/hr) }\end{array}$ & $9,8 \pm 6$ & 8,6 & 1,6 & 37,5 & 9,8 \\
\hline $\begin{array}{l}\text { Selenium } \\
(\mu \mathrm{g} / \mathrm{hr})\end{array}$ & $39 \pm 14$ & 40 & 12 & 63 & 30 \\
\hline
\end{tabular}

Median konsumsi antioksidan vitamin $\mathrm{A}$, vitamin $\mathrm{C}$, vitamin $\mathrm{E}$, zink dan selenium responden melebihi angka kecukupan gizi (tabel 2). Konsumsi maksimum antioksidan juga berkisar antara dua sampai tiga kali lipat dari angka kecukupan gizi.

Tabel 3. Distribusi Beta-Amyloid 40 dan Beta-Amyloid 42 Berdasarkan Cut-off Point (COP)

\begin{tabular}{ccccc}
\hline Penanda & $\mathbf{n}$ & $\%$ & $\begin{array}{c}\text { Nilai cut-off } \\
\text { point (COP) }\end{array}$ \\
\hline $\mathrm{A} \beta 40$ & & & & \\
& & & & \\
- & Rendah & 74 & 51 & $1233,4 \mathrm{pg} / \mathrm{ml}$ \\
$\mathrm{A} \beta 42$ & & 71 & 49 & \\
& & & & \\
- & Rendah & 72 & 49,7 & $4,6 \mathrm{pg} / \mathrm{ml}$ \\
- & Tinggi & 73 & 50,3 & \\
& & & & \\
\hline
\end{tabular}

Tabel 3 memperlihatkan hasil pemeriksaan laboratorium diketahui responden yang memiliki nilai beta-amyloid 40 rendah lebih banyak (51\%) dan betaamyloid 42 rendah lebih sedikit $(49,7 \%)$

Tabel 4. Distribusi Fungsi Kognitif Berdasarkan Skor MoCA-Ina

\begin{tabular}{lccc}
\hline Fungsi kognitif & Median & Min & Maks \\
\hline Normal $=62$ & 27 & 26 & 30 \\
Terganggu $=83$ & 18 & 9 & 25 \\
\hline
\end{tabular}


Tabel 4 menggambarkan jumlah responden yang memiliki fungsi kognitif terganggu lebih banyak dibanding responden yang memiliki fungsi kognitif normal yaitu masing-masing 83 orang $(57,2 \%)$ dan 62 orang (42,8\%). Median skor MoCA-Ina pada responden dengan fungsi kognitif normal adalah 27 dengan skor minimum 26 dan maksimum 30 . Sedangkan median pada reponden yang mempunyai fungsi kognitif terganggu adalah 18 dengan skor minimum 9 dan maksimum 25.

Tabel 5. Distribusi Konsumsi Antioksidan dengan Fungsi Kognitif

\begin{tabular}{|c|c|c|c|}
\hline \multirow{2}{*}{$\begin{array}{l}\text { Konsumsi } \\
\text { antioksidan }\end{array}$} & \multicolumn{2}{|c|}{ Fungsi kognitif } & \multirow[t]{2}{*}{$P$} \\
\hline & $\begin{array}{c}\text { Normal } \\
\text { Median } \\
\text { (min-maks) }\end{array}$ & $\begin{array}{c}\text { Terganggu } \\
\text { Median } \\
\text { (min-maks) }\end{array}$ & \\
\hline $\begin{array}{l}\text { Vitamin A } \\
(\mu g R E)\end{array}$ & $\begin{array}{c}826 \\
(220-1142)\end{array}$ & $\begin{array}{c}824 \\
(216-1130)\end{array}$ & 0,542 \\
\hline $\begin{array}{l}\text { Vitamin C } \\
(\mathrm{mg})\end{array}$ & $\begin{array}{c}96 \\
(2-194)\end{array}$ & $\begin{array}{c}75 \\
(20-190)\end{array}$ & 0,049 \\
\hline $\begin{array}{l}\text { Vitamin E } \\
(\mathrm{mg})\end{array}$ & $\begin{array}{c}18 \\
(6-40)\end{array}$ & $\begin{array}{c}16 \\
(5-38)\end{array}$ & 0,037 \\
\hline Zink (mg) & $\begin{array}{c}8,6 \\
(2,6-37,5)\end{array}$ & $\begin{array}{c}8,9 \\
(1,8-34,9)\end{array}$ & 0,496 \\
\hline $\begin{array}{l}\text { Selenium } \\
(\mu \mathrm{g})\end{array}$ & $\begin{array}{c}43 \\
(15-62)\end{array}$ & $\begin{array}{c}38 \\
(12-63)\end{array}$ & 0,333 \\
\hline
\end{tabular}

Uji Mann-Whitney

Terdapat hubungan yang signifikan antara konsumsi vitamin $\mathrm{C}$ dan vitamin $\mathrm{E}$ dengan gangguan fungsi kognitif yaitu masing-masing $p=0,049$ dan $p=0,037$. Sedangkan konsumsi vitamin $A$, zink dan selenium tidak berhubungan dengan gangguan fungsi kognitif.
Tabel 6. Distribusi Konsumsi Antioksidan dengan A 440 Plasma

\begin{tabular}{|c|c|c|c|}
\hline \multirow{2}{*}{$\begin{array}{l}\text { Konsumsi } \\
\text { antioksidan }\end{array}$} & \multicolumn{2}{|c|}{$\mathrm{A} \beta 40$} & \multirow[t]{2}{*}{$P$} \\
\hline & $\begin{array}{c}\text { Rendah }(\mathrm{n}=74) \\
\text { Median } \\
\text { (min-maks) }\end{array}$ & $\begin{array}{c}\text { Tinggi (n=71) } \\
\text { Median } \\
\text { (min-maks) }\end{array}$ & \\
\hline $\begin{array}{l}\text { Vitamin A } \\
\text { ( } \mu \mathrm{gRE})\end{array}$ & $\begin{array}{c}825 \\
(216-1140)\end{array}$ & $\begin{array}{c}826 \\
(220-1142)\end{array}$ & 0,484 \\
\hline $\begin{array}{l}\text { Vitamin C } \\
(\mathrm{mg})\end{array}$ & $\begin{array}{c}89 \\
(22-194)\end{array}$ & $\begin{array}{c}85 \\
(20-186)\end{array}$ & 0,761 \\
\hline $\begin{array}{l}\text { Vitamin E } \\
(\mathrm{mg})\end{array}$ & $\begin{array}{c}17 \\
(5-40)\end{array}$ & $\begin{array}{c}16 \\
(5-40)\end{array}$ & 0,603 \\
\hline $\begin{array}{l}\text { Zink } \\
\text { (mg) }\end{array}$ & $\begin{array}{c}8,7 \\
(2,2-37,5)\end{array}$ & $\begin{array}{c}8,5 \\
(1,8-34,9)\end{array}$ & 0,953 \\
\hline $\begin{array}{l}\text { Selenium } \\
(\mu g)\end{array}$ & $\begin{array}{c}40 \\
(15-63)\end{array}$ & $\begin{array}{c}42 \\
(12-62)\end{array}$ & 0,998 \\
\hline
\end{tabular}

Uji Mann-Whitney

Tingkat $A \beta 40$ rendah lebih banyak terdapat pada responden yang mengkonsumsi vitamin $A$ dan selenium sedikit dan konsumsi vitamin $\mathrm{C}$, vitamin $\mathrm{E}$ dan zink yang banyak. Namun tidak terdapat hubungan yang signifikan antara konsumsi antioksidan tersebut dengan nilai $A \beta 40$ plasma $(p>0,05)$.

Tabel 7. Distribusi Konsumsi Antioksidan dengan A 4 2 Plasma

\begin{tabular}{|c|c|c|c|}
\hline \multirow{2}{*}{$\begin{array}{l}\text { Konsumsi } \\
\text { antioksidan }\end{array}$} & \multicolumn{2}{|c|}{$A \beta 42$} & \multirow{2}{*}{$\begin{array}{c}P \\
\text { value }\end{array}$} \\
\hline & $\begin{array}{c}\text { Rendah (n=72) } \\
\text { Median } \\
\text { (minimum- } \\
\text { maksimum) }\end{array}$ & $\begin{array}{c}\text { Tinggi (n=73) } \\
\text { Median } \\
\text { (minimum- } \\
\text { maksimum) }\end{array}$ & \\
\hline $\begin{array}{l}\text { Vitamin A } \\
(\mu g R E)\end{array}$ & $\begin{array}{c}826(216- \\
1140)\end{array}$ & $\begin{array}{c}822(250- \\
1142)\end{array}$ & 0,803 \\
\hline $\begin{array}{l}\text { Vitamin C } \\
(\mathrm{mg})\end{array}$ & $83(20-194)$ & $90(22-186)$ & 0,636 \\
\hline $\begin{array}{l}\text { Vitamin E } \\
(\mathrm{mg})\end{array}$ & $17(5-40)$ & $16(5-40)$ & 0,594 \\
\hline Zink (mg) & $8,6(1,8-37,5)$ & $8,8(2,2-31)$ & 0,691 \\
\hline $\begin{array}{l}\text { Selenium } \\
(\mu \mathrm{g})\end{array}$ & $41(12-63)$ & $40(15-62)$ & 0,989 \\
\hline
\end{tabular}

Tabel 7 menunjukkan bahwa tingkat $A \beta 42$ rendah terdapat pada responden yang konsumsi antioksidan vitamin $A$, vitamin $E$ dan zink 
lebihbanyak dan konsumsi vitamin $\mathrm{C}$ dan zink yang sedikit. Tidak ada berhubungan bermakna secara statistik antara konsumsi antioksidan tersebut dengan tingkat $A \beta 42$ plasma ( $p>0,05)$.

Tabel 8. Distribusi Responden menurut $A \beta 40$ dan Aß42 Plasma dengan Fungsi Kognitif

\begin{tabular}{|c|c|c|c|c|c|c|c|}
\hline \multirow{4}{*}{ Penanda } & \multicolumn{5}{|c|}{ Fungsi kognitif } & \multirow{4}{*}{$\boldsymbol{P}$} & \multirow{4}{*}{ OR } \\
\hline & \multicolumn{2}{|c|}{ Terganggu } & \multicolumn{3}{|c|}{ Normal } & & \\
\hline & & & & & & & \\
\hline & $\mathbf{n}$ & $\%$ & $\mathbf{n}$ & $\%$ & $\mathbf{n}$ & & \\
\hline \multicolumn{8}{|l|}{$A \beta 40$} \\
\hline Rendah & 48 & 64,9 & 26 & 35,1 & 74 & 0,058 & 0,53 \\
\hline Tinggi & 35 & 49,3 & 36 & 50,7 & 71 & & \\
\hline \multicolumn{8}{|l|}{$A \beta 42$} \\
\hline Rendah & 44 & 61,1 & 28 & 48,9 & 72 & 0,350 & 0,73 \\
\hline Tinggi & 39 & 53,4 & 34 & 46,6 & 73 & & \\
\hline Total & 83 & 57,2 & 62 & 42,8 & 145 & & \\
\hline
\end{tabular}

uji Chi-square

Tabel 8 menggambarkan hubungan antara nilai $A \beta 40$ dan $A \beta 42$ responden dengan fungsi kognitif Terdapat sebanyak 48 orang (64,9\%) responden yang memiliki nilai $A \beta 40$ rendah dan mengalami gangguan fungsi kognitif. Hasil uji Chi-square disimpulkan tidak terdapat hubungan bermakna antara nilai $A \beta 40$ dengan gangguan fungsi kognitif $(p=0,058)$ dengan kecenderungan mengalami gangguan fungsi kognitif sebesar 0,53. Responden yang memiliki nilai $A \beta 42$ rendah dan memiliki fungsi kognitif terganggu sebanyak 44 orang $(61,1 \%)$, sedangkan responden yang memiliki beta-amyloid rendah dan fungsi kognitif normal sebanyak 28 orang (48,9\%). Analisis data diketahui tidak ada hubungan bermakna antara $A \beta 42$ plasma dengan fungsi kognitif $(p>0,350)$ dan responden yang memiliki tingkat $A \beta 42$ rendah memiliki kecenderungan mengalami gangguan fungsi kognitif sebesar 0,73 kali dibanding yang memiliki tingkat $A \beta 42$ tinggi.

\section{PEMBAHASAN}

Menurut letak geografis dan potensi sumber daya alam berupa hasil perkebunan berupa sayur dan buah, lansia yang berada pada lokasi penelitian tidak mengalami kesulitan dalam memperoleh sumber makanan yang banyak mengandung antioksidan. ${ }^{9}$

Persentase responden berdasarkan kelompok umur terbanyak adalah 60 sampai 64 tahun dan perempuan lebih banyak dari laki-laki. Ini sesuai dengan jumlah penduduk menurut golongan umur dan jenis kelamin di Sumatera Barat. ${ }^{10}$ Sekolah Dasar (SD) ataupun yang sederajat, baik tamat ataupun tidak merupakan pendidikan terakhir responden terbanyak (73,8\%). Hal ini karena sebagian besar responden sulit mendapatkan pendidikan karena faktor ekonomi dan kondisi negara pada saat perjuangan dan mempertahankan kemerdekaan.Pekerjaan tani atau buruh merupakan pekerjaan responden paling banyak (84\%) diikuti PNS/TNI (55\%) dan pedagang (5\%). Sesuai dengan kondisi geografis dan potensi daerah Kabupaten Lima Puluh kota bahwa sebagian besar terdiri dari perbukitan sehingga sangat cocok untuk bertani dan berkebun.

Sebagian besar responden tidak merokok (80\%) dan $5,5 \%$ perokok berat. $\mathrm{Hal}$ ini mungkin disebabkan sebagian besar responden adalah perempuan (walaupun ada beberapa perempuan yang merokok). Merokok dapat mengurangi usia harapan hidup \pm 10 tahun, atau dengan kata lain apabila seseorang tidak merokok berarti menambah usia harapan hidup rata-rata 10 tahun. $^{11}$

Body Mass Index (BMI) responden pada penelitian ini sebagian besar adalah normal. Pengukuran tinggi badan responden dengan berdiri tegak dan diukur menggunakan microtoise merupakan pengukuran untuk lansia kondisi sehat dan dapat berdiri tegak. Pada dasarnya proses penuaan menyebabkan perubahan komposisi tubuh lansia seperti kehilangan berat dan tinggi badan, massa otot dan peningkatan massa lemak $^{12}$. Sehingga pengukuran tinggi badan yang ideal adalah menggunakan tinggi lutut, selanjutnya dilakukan penghitungan BMI. $^{13}$ Hampir semua responden tidak mengalami diabetes melitus (92,4\%) dan lebih dari separuh $(59,3 \%)$ tidak mengalami hipertensi.

Tabel 2 menggambarkan konsumsi anti oksidan dari makanan yang diperiksa dengan FFQ. Penggunaan FFQ pada lansia merupakan tantangan tersendiri karena berbagai faktor seperti menurunya fungsi memori, pendengaran dan penglihatan. Namun FFQ memberikan hasil lebih cocok dibanding metode recalls 24 jam karena lansia memiliki memori jangka panjang lebih baik daripada jangka pendek dan lebih mudah menjawab pertanyaan terbuka dibandingkan dengan terstruktur. ${ }^{14}$ Median dari vitamin A, vitamin C, vitamin $E$, zink, dan selenium pada penelitian ini lebih 
tinggi dari AKG 2012. Penelitian Helmizar dkk di tahun 2010, pada populasi dewasa umur 30-65 tahun etnis Minangkabau di Kota Padang menunjukkan bahwa konsumsi vitamin $\mathrm{C}$ dan vitamin $\mathrm{E}$ lebih tinggi dari $\mathrm{AKG}$ $2004 .^{15}$ Buah-buahan dan sayur-sayuran merupakan sumber vitamin $C$ sedangkan minyak sayur, kacangkacangan dan biji-bijian merupakan sumber vitamin $\mathrm{E}$. Beberapa sumber saat ini menyarankan konsumsi vitamin C dari diet (RDA) adalah 75-125 mg perhari yang disesuaikan dengan usia, jenis kelamin, kehamilan dan kebiasaan merokok. ${ }^{16}$ Banyak faktor yang mempengaruhi konsumsi makanan seseorang, diantaranya kebiasaan atau tradisi, tekanan sosial ekonomi dan nilai gizi dalam makanan. Secara umum konsumsi makanan lansia di Indonesia adalah menyehatkan karena banyak mengandung padi, buah, sayur dan ikan. ${ }^{13}$

Analisis secara statistic pada tabel 5 menunjukkan bahwa terdapat hubungan yang signifikan antara konsumsi vitamin $\mathrm{C}$ dan vitamin $\mathrm{E}$ dari makanan dengan gangguan fungsi kognitif ( $p=0,49$ dan $p=0,037)$. Penelitian disebuah panti jompo di Jakarta dengan pemeriksaan MMSE menunjukkan bahwa konsumsi vitamin C yang tinggi (101,15 $\mathrm{mg} /$ hari) berkorelasi dengan tingginya skor MMSE (Mini-Mental State Examination). ${ }^{17}$ Devore dkk pada tahun 2010 menyimpulkan bahwa konsumsi makanan yang kaya vitamin $\mathrm{E}$ (rata-rata $13,9 \mathrm{mg} /$ hari) tetapi bukan vitamin $\mathrm{C}$, beta-karoten dan flovonoid dihubungkan dengan penurunan resiko selama 10 tahun demensia. ${ }^{18}$ Konsumsi antioksidan dalam makanan memberikan perlindungan terhadap kerusakan oksidatif yang menyebabkan penurunan fungsi kognitif pada penuaan normal dan pada penyakit Alzheimer. Vitamin C mampu menetralkan radikal bebas dengan mendonorkan satu elektronnya dan membentuk radikal monodehydroascorbat yang tidak berbahaya. Selain itu vitamin $\mathrm{C}$ dapat mendaur ulang vitamin $\mathrm{E}^{16}$

Pada penelitian ini konsumsi suplemen dari vitamin dan mineral tidak diperiksa karena konsumsi vitamin dan mineral tidak menggambarkan pola makanan responden perhari walaupun bioavailabititasnya tidak terlalu berbeda. ${ }^{19}$

Silva $d k k$ pada tahun 2014 melakukan studi meta-analisis pada 3397 publikasi yang menghubungkan status nutrisi dalam tubuh dengan penyakit Alzheimer. ${ }^{20}$ Hasil studi tersebut menyimpulkan bahwa konsentrasi rendah asam folat, vitamin $A$, vitamin $C$, vitamin $E$, vitamin $B 12$ berhubungan signifikan dengan kejadian Alzheimer $(p<0,001)$, namun tidak berhubungan signifikan dengan konsentrasi zink yang rendah $(p=0,050)$ dan vitamin $D$ yang rendah $(p=0,075)$.

Hubungan konsumsi selenium dari makanan terhadap fungsi kognitif diteliti oleh Gao dkk pada tahun 2007. Kadar selenium yang rendah pada pada kuku dan kuintil selenium berhubungan signifikan dengan rendahnya fungsi kognitif pada lansia di Cina yang tinggal di desa. ${ }^{21}$

Penelitian pada hewan coba yang dilakukan Nishida dkk pada tahun 2009 untuk mengetahui hubungan antioksidan dengan beta-amyloid menyimpulkan bahwa rendahnya vitamin $E$ meningkatkan timbunan beta-amyloid karena terjadi penurunan aliran (clearance) beta-amyloiddari otak ke pembuluh darah pada tikus model Alzheimer. ${ }^{22}$

Penelitian cross sectional yang dilakukan pada tahun 2012 untuk mengetahui hubungan antara konsumsi makanan (asam lemak jenuh, asam lemak tak jenuh rantai tunggal, omega-3 PUFA, omega-6 PUFA, vitamin C, vitamin E, $\beta$-karoten, vitamin B12, Folat dan vitamin $D)$ dengan $A \beta 40$ dan $A \beta 42$ plasma pada lansia yang berumur $\geq 65$ tahun menyimpulkan bahwa konsumsi makanan yang banyak mengandung omega-3 PUFA berhubungan dengan tingkat $A \beta 42$ plasma. $^{23}$

Responden yang memiliki tingkat $A \beta 40$ rendah banyak mengalami gangguan fungsi kognitif $(64,9 \%)$, namun hubungan ini tidak bermakna secara statisik ( $p=0,058)$ (Tabel 8). Begitu juga hubungan antara tingkat $A \beta 42$ rendah dengan gangguan fungsi kognitif pada penelitian ini tidak bermakna $(p=0,350)$. Kesimpulan yang sama diperoleh dari penelitian 
Pesini P dkk pada tahun 2012, responden yang memiliki tingkat $A \beta 40$ dan $A \beta 42$ rendah lebih banyak mempunyai gangguan kognitif berat dibanding gangguan fungsi kognitif sedang. ${ }^{24} \mathrm{Hal}$ ini mungkin disebabkan adanya gangguan produksi dan distribusi $A \beta 40$ dan $A \beta 42$ di dalam plasma. Gangguan sawar otak pada stadium lanjut demensia yang menyebabkan terbatasnya aliran beta-amyloid dari otak dan cairan serebrospinal ke perifer, sehingga terjadi timbunan diotak dan menyebabkan kematian sel saraf. ${ }^{25}$ Faktor lain yang menentukan gangguan fungsi kognitif adalah bentuk oligomer $A B$ (yang bersifat lebih toksik) dan lokasi terbentuknya plak amyloid. $^{26}$

Keterbatasan penelitian ini adalah bahwa pengambilan sampel penelitian sebaiknya mempunyai tingkat pendidikan yang sama agar tidak terjadi bias dalam pemeriksaan MoCA-Ina. Pemeriksaan FFQ pada responden yang memiliki skor MoCA-Ina rendah (9) berpengaruh pada hasil pendataan makanan, sehingga terjadi underestimate.

\section{KESIMPULAN}

Terdapat hubungan yang bermakna secara statistik antara konsumsi vitamin C dan vitamin $\mathrm{E}$ dengan gangguan fungsi kognitif pada lansia. Tidak terdapat hubungan yang bermakna antara konsumsi antioksidan dengan beta-amyloid40 dan betaamyloid42 plasma pada lansia dan tidak terdapat hubungan yang bermakna antara beta- amyloid40 dan beta-amyloid42 plasma dengan gangguan fungsi kognitif pada lansia.

Disarankan untuk penelitian selanjutnya pada sampel yang memiliki tingkat pendidikan yang sama agar tidak terjadi bias saat pemeriksan fungsi kognitif dengan MoCA-Ina.Sebaiknya untuk mengetahui berapa banyak konsumsi antioksidan pada responden dihitung juga konsumsi suplemen yang dapat mempengaruhi fungsi kognitif dan kadar beta-amyloid.

\section{DAFTAR PUSTAKA}

1. Turana Y. Stimulasi otak pada kelompok lansia di komunitas, Buletin Jendela Data dan Informasi Kesehatan. Kementrian Kesehatan RI.2013

2. Pandey KB, Ibrahim RS. Marker of oxidative stress in erytrocytes and plasma during aging in human. J Oxidative medicine and celluler Longevity. 2010;3(1):2-12.

3. Carvellati C, Romani A, Seripa D, Cremonini E, Bosi C, Magon S, et al, Systemic oxidative stress and convertion to dementia of elderly patients with mild cognitive impairment. Biomed Research International. 2014;7.

4. Butterfield DA, Aaron MS, Rukhsana S. Amyloid $\beta$-Peptide (1-42) induced oxidative stress in Alzheimer disease: Importance in disease pathogenesis and progression. J. Antioxidans and redox signaling. 2013;19(8).

5. Duron E, Oliver H. Vascular risk factor, cognitive decline and dementia. J Vasculer health and Risk Management. 2008;4(2):363-81.

6. Andrade C, Radhakrishnan R. The prevention and treatment of cognitive decline and dementia: An overview of recent research on experimental treatments. Indian J Psychiatry. 2009;51(1):1225.

7. Nan Hu, Jin-Tai Hu, lin Tan, Ying-Li Wang, lei Sun, Lan Tan. Nutrition and the risk of Alzheimer's disease. Biomed Research International. 2013;12.

8. Willett W. Nutritional epidemyology. Edisi ke-2. New York : Oxford University Press; 1998.

9. BPS Lima Puluh Kota. Ringkasan eksekutif sektor pertanian 2012 (diunduh 5 Oktober 2014). Tersedia dari: URL: HYPERLINK http://www.limapuluhkotakab.bps.go.id/web/imag es/publikasi/2012/asp/files/search/searchtext.xm

10. BPS. Pembangunan manusia berbasis gender, Kerjasama Kementrian Pemberdayaan Perempuan dan Perlindungan Anak dengan Badan Pusat Statistik. Jakarta; 2013.

11. Departemen Kesehatan RI, Pedoman pembinaan kesehatan usia lanjut bagi petugas kesehatan., Direktorat Bina Gizi Masyarakat Ditjent Binkesmas Depkes RI, Jakarta; 2008.

12. Shatenstein $B$, Kergoat MJ, Nadon S, Anthropometric changes over 5 years in elderly Canadians by age, gender, and cognitive status. J Gerontol. 2001;56A(8):M483-M8.

13. Setiati S, Harimurti K, Dewiasty E, Istanti R, Mupangati YM, Ngestiningsih D, et al. Profile of food and nutrient intake among Indonesian 
elderly population and factors associated with energy intake: a Multi-center study. Indones J Intern Med. 2013;45(4):265-74.

14. Eysteinsdottir T, Thorsdottir I, Gunnarsdottir I, Steingrimsdottir L. 1 Assessing validity of a short food frequency questionnaire on present dietary intake of elderly Icelanders. Nutrition Journal. 2012;11:12.

15. Helmizar, Jalal F, Liputo NI. Hubungan tingkat konsumsi antioksidan dengan profil lipid darah orang dewasa etnis Minangkabau di Kota Padang, Majalah Kedokteran Indonesia. 2010;60(8):356-63.

16. Horrison FE. A critical review of vitamin $\mathrm{C}$ for the prevention of age-related cognitive decline and Alzheimer's disease. J Alzheimers Dis. 2012; 29(4):711-26.

17. Tani J, Ivan $R$, Widjaja, Irwin $T$, Irandi $P$, Pratomo, Siagian I, Indra F, Zarni A, Saptawati B. Association between dietary intake of vitamin $A$, $C$, and $E$ as antioxidants and cognitive function in the elderly at a nursing home, Medical Journal of Indonesia. 2007; Vol:15(4).

18. Devore EE, Grodstein F, van Rooij FJ, Hofman A, Stampfer MJ, Witteman JC, Breteler MM. Dietary antioxidants and long-term risk of dementia. Arch Neurol. 2010;67(7):819-25.

19. Carr AC, Vissers M. Synthetic or food-derivated vitamin C-Are they equally bioavailable? Nutrients. 2013;5:4284-304.

20. Silva S Lopes, Vellas B, Elemans S, Luchsinger J, Kamphuis P, Yaffe K, Sijben J, Groenendijk
$\mathrm{M}$, Stijnen $\mathrm{T}$ - Plasma nutrient status of patients with Alzheimer's disease: Systematic review and meta-analysis. Alzheimers Dement. 2014; 10(4):485-502.

21. Gao $S$, Jin $Y$, Hall KS, Liang $C$, Unverzagt FW, $\mathrm{Ji}$, et al. Selenium level and cognitive function in rural elderly Chinese. Am J Epidemiol. 2007;165(8):955-65.

22. Nishida $\mathrm{Y}$, Ito $\mathrm{S}$, Othsuki $\mathrm{S}$, Yamamoto $\mathrm{N}$, Takahashi T, Iwata N, et al. Depletion of vitamin $E$ increases amyloid $\beta$ accumulation by decreasing its clearances from brain and blood in a mouse model of Alzheimer disease. $J$ Biol Chem. 2009;284(48):33400-8.

23. Yian Gu' Scarmeas N. Dietary patterns in Alzheimer's Disease and Cognitive Aging. Curr Alzheimer Res. 2011;8(5):510-9.

24. Pesini P, Virginia Pérez-Grijalba, Inmaculada Monleón, Mercè Boada, Lluís Tárraga, Pablo Martínez-Lage, et al. Reliable Measurements of the $\beta$-Amyloid Pool in Blood Could Help in the Early Diagnosis of AD. International Journal of Alzheimer's Disease. 2012.

25. Sobow T, Flirski M, Kloszewska I, Liberski PP, Plasma level of $A \beta$ peptides are altered in amnestic mild cognitive impairment but not in sporadic Alzheimer's disease. Acta Neurobiol Exp.2005;65:117-24.

26. O'Brien JO, Erkinjuntti T, Reisberg B, Vascular cognitive impairment. Lancet Neurol. 2003;2:8998 